\title{
Merocyanine dye mixed LB film photo-rechargeable battery by current controlled polymerization method
}

\section{電流制御重合法によるメロシアニン色素混合 L B 膜光蕃電池}

\author{
Shinichi TANIGUCHI and Sadao UEGUSA \\ Department of Electrical Engineering, Tokai University, 1117 Kitakaname, Hiratsuka, Kanagawa, 259-1292, JAPAN \\ TEL : 81-463-58-1211 (EXT. 4162)
}

\begin{abstract}
Kenichi ro NAKAMURA
Department of Optical Engineering, Tokai University, 1117 Kitakaname, Hiratsuka, Kanagawa, 259-1292, JAPAN

TEL : 81-463-58-1211 (EXT. 4423)

( Received 15, November 1999 Accepted 6, March 2000 )

The photo-rechargeable battery was produced by the merocyanine dye mixed LB film which functioned as a photo-catalyst. Poly-Pyrrole film which is the storage layer was polymerized electrolytically by current control. As a resalt, very small selfdischarge was obtained, when the polymerization current was small.
\end{abstract}

KEYWORDS : photo-rechargeable battery, current controlled polymerization, merocyanine dye mixed LB film

\section{I . INTRODUCTION}

感光色素として知られているメロシアニン色素（以下、My 色 秦と記す）を LB 法を用いて製膜すると、光電変換の機能を有す る単分子を規則的に累積させた超薄膜が得られる。 ${ }^{1}$ また、ピロー ルを電解重合法を用いて重合させると、導電性高分子であるポリ ピロール膜が得られる。2

本研究では，My 色素 LB 膜を光触媒として用いた。こを、 蓄電材料であるポリピロール膜面上に超薄膜として形成し、光電 変換と蓄電を同一素子で行う光蓄電池を作製した。また、電解重 合の際に、重合電流を小さく制御することによってポリピロール が選抧的に電解重合されることが期待でき、膜の規則性の向上を 目指すことができる。これにより、重合電流について光蓄電池の 性能が最大となるポリピロール膜作製条件を比較・検討した。

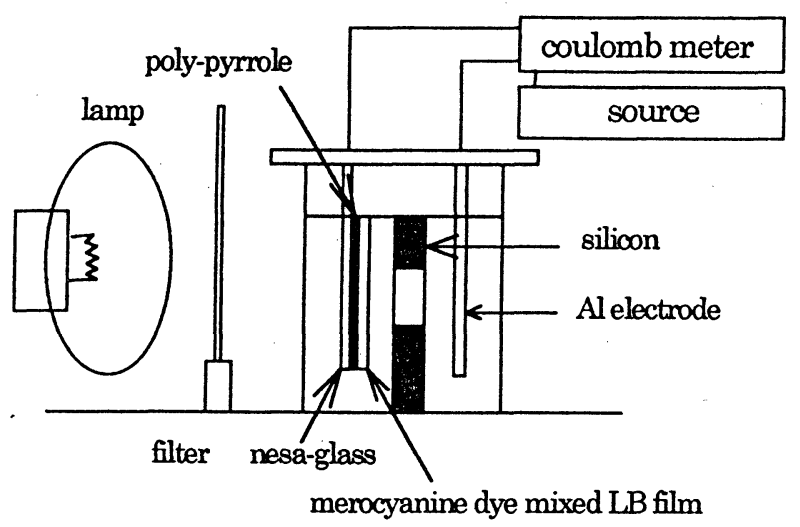

FIG.1. The wiring diagram of experimental apparatus.

\section{EXPERIMENT}

（a）重合電流制御による電解重合法

膜の電解重合には、 $50 \mathrm{ml}$ のビーカーに溶媒としてアセトニト

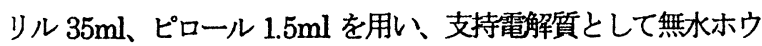
フッ化リチウム $100 \mathrm{mg}$ を用い ポリビニルアルコール $0.1 \mathrm{mg} を$ 入れ，十分㨪挥する。その後、真空引きを行い、これを電解質溶 液とする。電極は，主電極にネサガラス，対向電極にアルミ板を 用い両電極を $2 \mathrm{~cm}$ の間隔て溶液中に $4 \mathrm{~cm}^{2}$ 挿入した。これに 電源を Fig.1 のように配線し電圧を 5V 印加することでネサガラ ス面に 2.0 クーロン電解重合した。重合電荷量はクーロンメータ で設定した。

電解重合の際、正極と負極との間にシリコン障壁板を入れ、両 電極を結ぶ中心点を中心として穴を開け、開口面積を変化させる ことにより、重合電流を制御した。この理由は、より低温下で重 合した膜程、その構造規則性に優れ、膜の導電率の向上が影著で あったことと現象的に類似する。 ${ }^{3}$

（b）重合電流変化による My 色素混合 LB 膜光蓄電池の 光蓄電特性

重合電流を $6.0 \mathrm{~mA}, 11.2 \mathrm{~mA}$ とした場合と、制御なしの重合電 流 $28.0 \mathrm{~mA}$ において電解重合を行い $\mathrm{LB}$ 膜採取時の表面圧は $30 \mathrm{mN} / \mathrm{cm}$ 、累積数は 5 層に固定した。作製した膜こレフレック スランプを用いて光照射した。試料面における光出力を $40 \mathrm{~mW}$ に設定して、光照射を 1 分間行い、その後 1 分間光照射を停止 する。このサイクルを 5 回繰り返し、蓄電電圧值の変化を測定 した。 


\section{RESULTSAND DISCUSSION}

以上の実験により以下の結果を得た。

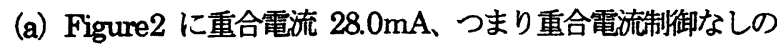
試料における光照射一蓄電電位特性を示す。同図では明らかに 光照射時に電圧值が上昇し、一照射当りの平均蓄電電位は 16.7 $\mathrm{mV}$ である。非照射時には電圧值が下降し、自己放電している

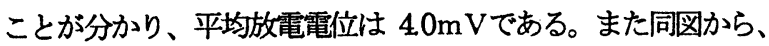
放電より蓄電の方が上回っており、自己放電率は $24.0 \%$ な゙あ。

(b) Figure3 に重合電流を $6.0 \mathrm{~mA}$ に抑えた試料における光照 射一蓄電電位特性を示す。同図でも光照射時に電圧值が上昇し、 非照射時には放電し、平均蓄電電位 $10.7 \mathrm{mV}$, 平均放電電位 0.6 $\mathrm{mV}$ である。Figure2 と比較すると、非照射時の自己放電が栖端 に小さく、自己放電率惊ずか $5.4 \%$ である。

(c) Figure4 に各重合電流で製作した試料に対する光照射実験 において観測された自己放電特性を示す。最も自己放電が少な いのは、重合電流を $6.0 \mathrm{~mA}$ と小さく制御した場合であった。

(d) Figure5 に各重合電流での重合所要時間と、Fig.4 のグラ フの傾きについて示す。重合電流を小さく制御した方が、自己 放電による電圧降下は小さく、明らかにそれに反比例して重合 所要時間は長くなる傾向がある。

以上の理由として、重合電流を低く抑え、重合所要時間が長 くなればなるほど、電解重合が選択的に行われる。つまり、膜 構造が規則正しい重合膜が得られると考えられる。すなわち、 禁制帯中のトラップレベルの数が減少し、蓄電電位が上昇しや

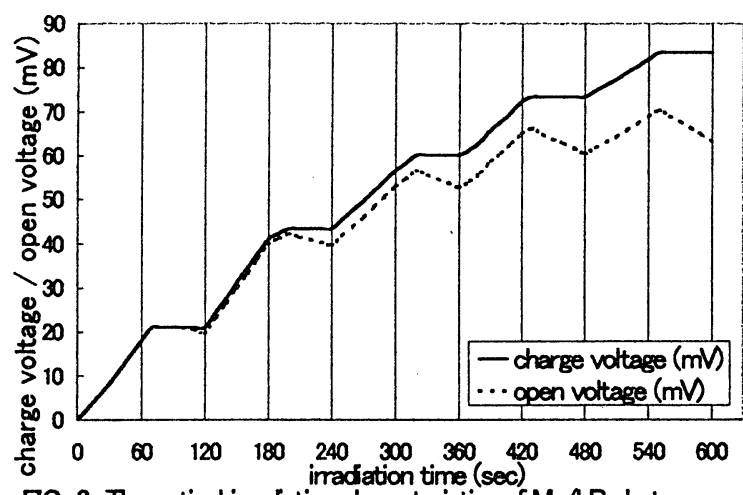

FG. 2. The optical irradiation characteristics of $M / 1 B$ photo rechargeable battery by current controlled polymerization method

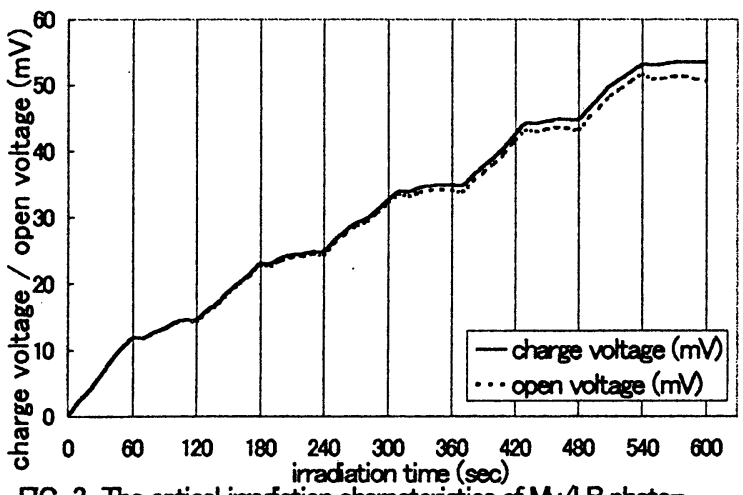

FG. 3. The optical irraciation characteristics of $M y / B$ photo rechargeable battery by current controlled polymerization method
すくなる。ゆえに、光蓄電池としての性能が向上し、自己放電 が減少したと考えられる。

\section{CONCLUSION}

1）重合の際、電極間にシリコン障壁板を入れ重合電流を制御し た膜の使用で、自己放電が顕著に小さくなることを確認した。

2）重合電流を低く抑えて電解重合を行うと、重合所要時間が長 くなり、これによって構造規則性の高い重合膜が得られる。 これが自己放電電圧が影著に減少した理由である。

3）以上の理由から、本光蓄電池は、現在のレベルで最も良い性 能を示した。

\section{REFERENCES}

${ }^{1}$ Kliyama, An organic ultra thin film, Sangyou write, (1992) p.122 125.

${ }^{2}$ K.Yoshino, Foundation and application of conducting polymer, Sangyou write, (1988) p.139 177.

${ }^{3}$ S.Uegusa, Some properties of electrochemically polymerized PPy films and its application to FET device, Industry science laboratory research report, (1988) p.14 16.
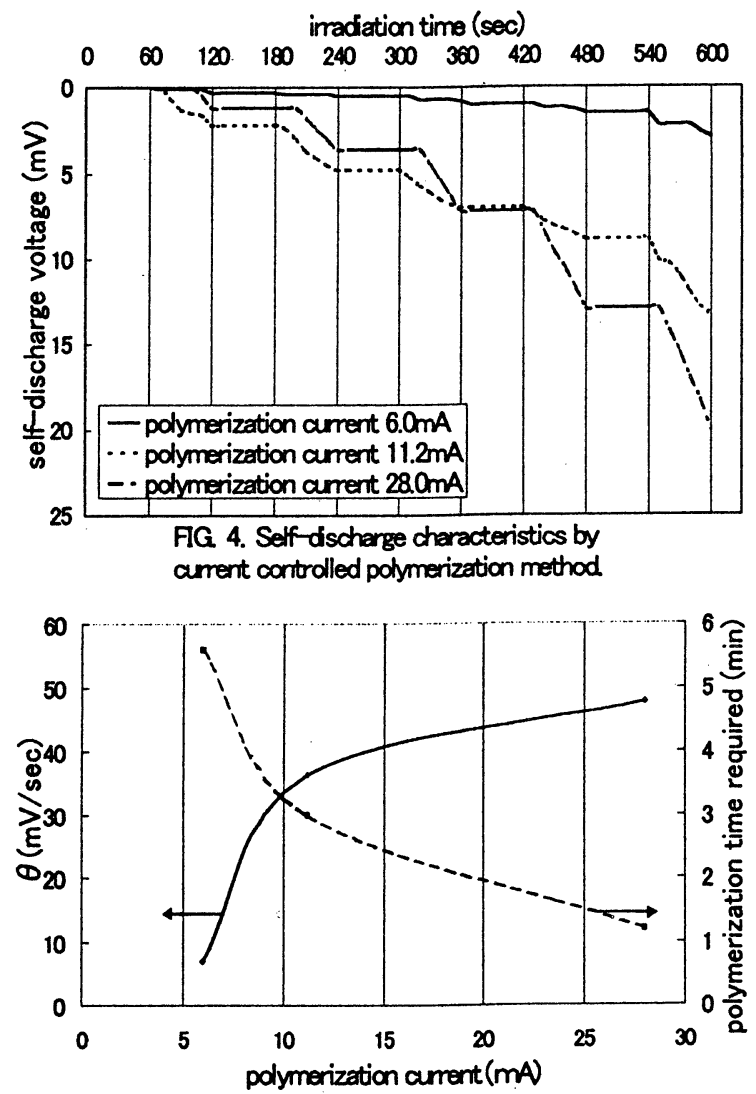

FG 5. Polymerization current and $\theta$ characteristics by current controlled polymerization method

Presented at ' 99 SAS Intelligent Symposium 